UDC 004.942:539.3

D.V. Lazareva, $\mathrm{PhD}$,

M.G. Suryaninov, DEng, Prof.

Odessa National Polytechnic University, 1 Shevchenko Ave., 65044 Odessa, Ukraine; e-mail: dedushka27@te.net.ua

\title{
MATHEMATICAL MODEL OF COMPLEX TECHNICAL ASYMMETRIC SYSTEM BASED ON NUMERICAL-ANALYTICAL BOUNDARY ELEMENTS METHOD
}

\begin{abstract}
Д.В. Лазарєва, М.Г. Сур'янінов. Математична модель складної асиметричної технічної системи на основі чисельно-аналітичного методу граничних елементів. Запропоновано нову математичну модель асиметричної несучої конструкції рамного типу, побудовану на основі чисельно-аналітичного методу граничних елементів. Для описання розрахункової схеми використано теорію графів. При побудові моделі враховано ефект стиснутого крутіння елементів рами, наявність якого зумовлена тим, що ці елементи є тонкостінними. Розглянуто побудову моделі реально експлуатованого об'єкта у вигляді двохосьового напівпричепа-платформи. Для реалізації алгоритму методу граничних елементів отримано аналітичні вирази фундаментальних функцій і компонентів вектора навантаження. Виконано розрахунки напівпричепа на основі двох різних моделей - скінченно-елементної і гранично-елементної. Аналіз показав, що похибка між результатами розрахунків, отриманими на основі двох чисельних методів, і експериментальними даними, становить близько 4 \%, що свідчить про адекватність запропонованої математичної моделі.

Ключові слова: математична модель, метод граничних елементів, метод скінчених елементів, САПР, орієнтований граф, тонкостінний стрижень.
\end{abstract}

D.V. Lazareva, M.G. Suryaninov. Mathematical model of complex technical asymmetric system based on numerical-analytical boundary elements method. A new mathematical model of asymmetric support structure frame type is built on the basis of numerical-analytical boundary elements method (BEM). To describe the design scheme used is the graph theory. Building the model taken into account is the effect of frame members restrained torsion, which presence is due to the fact that these elements are thin-walled. The built model represents a real object as a two-axle semi-trailer platform. To implement the BEM algorithm obtained are analytical expressions of the fundamental functions and vector load components. The effected calculations are based on the semi-trailer two different models, using finite elements and boundary elements methods. The analysis showed that the error between the results obtained on the basis of two numerical methods and experimental data is about $4 \%$, that indicates the adequacy of the proposed mathematical model.

Keywords: mathematical model, boundary element method, finite element method, CAD, directed graph, thin-wall bar.

Introduction. At many technical objects in quality of the main supporting structure is used a system, consisting of cross beams interconnected into a single unit by welding, riveting or bolting, and further fixed with various kinds of inserts, angular elements etc. Usually, this kind of design is called frames. This title does not seem well argued justified, since space frames consists of flat frames, i.e. of elements that lie in the same plane. This design includes an asymmetry in different directions, so further we shall identify this class of objects as "asymmetric complex technical system" (ACTS)

Literature review. Extensive and asymmetric geometry of these systems, the presence of vastly different configurations and elements' operating conditions make impossible the use of common analytical methods (forces method of and displacement method) for their calculation. The ACTS calculations can be unified only on the basis of numerical methods, that became possible with a wide spread use of modern computers technology and high-end CAD systems. The vast majority of existing CAD (95\%) is based on the same mathematical model, the finite elements method (FEM) [1,2]. Upon thorough study of the problem we propose a new model based on numerical-analytical boundary elements method [3].

DOI 10.15276/opu.2.46.2015.24

(C) 2015 The Authors. This is an open access article under the CC BY license (http://creativecommons.org/licenses/by/4.0/). 
The Aim of the Research is to decrease the period of designing the asymmetric complex technical systems with the auxiliary of a mathematical ACTS model based on numerical-analytical boundary element method.

Main Body. We build a mathematical ACTS model of a biaxial semitrailer platform (Fig. 1) on the basis of numerical and analytical boundary element method (N\&A BEM). This trailer represents an actually operated facility to transport a 40 -foot or two 20-foot containers type 1AA and 1CC within the port using different types of truck tractors. Weight of transported cargo: 60 tons; weight of the semitrailer: 7 tons; dimensions $-13000 \times 2700 \mathrm{~mm}$.

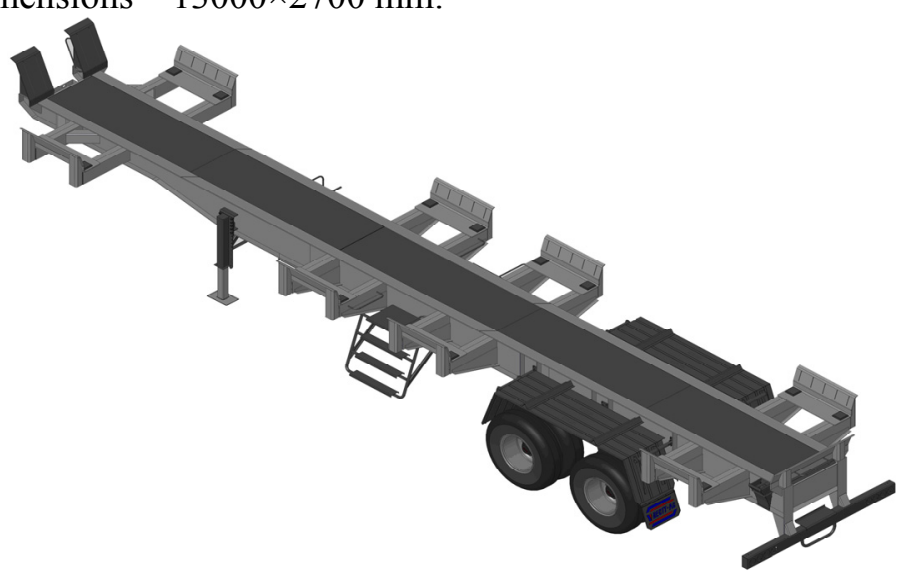

Fig. 1. Biaxial semitrailer-platform

To build the calculation scheme, in accordance with the concept of N\&A BEM [3], we divide the longitudinal elements (spars) and transversal one (crosses) into one-dimensional modules, i.e., we construct a directed graph for the structure under consideration (Fig. 2).

The console load does often involves concentrated forces $P$ and the moments $M$, applied to the respective points (indicated by numbers in Fig. 2).

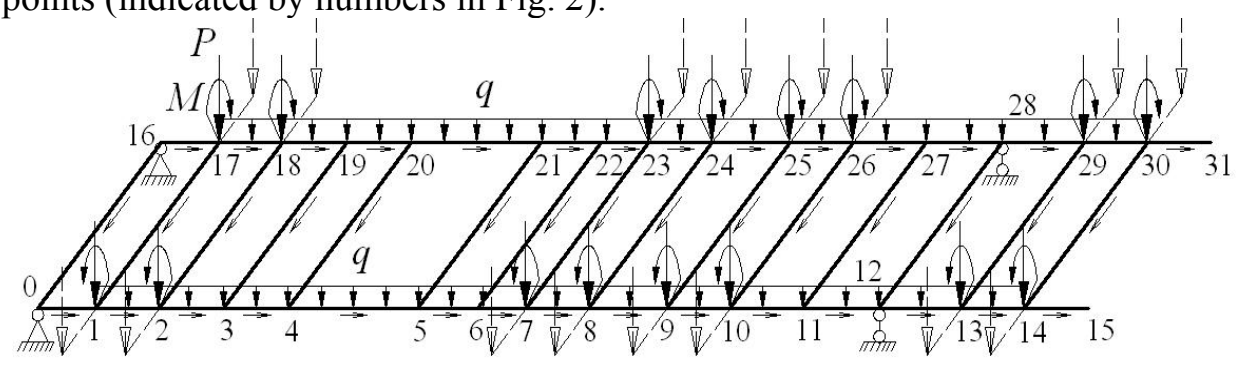

Fig. 2. Decomposing the calculation scheme into one-dimensional modules

When design methods practiced until recently, each module of the system was considered as a beam with two supports, and the stress at a given point was determined without respect to longitudinal forces

$$
\sigma_{z}=\frac{M_{x}}{I_{x}} y+\frac{M_{y}}{I_{y}} x
$$

This model is described with differential equations

$$
\left\{\begin{array}{l}
E I_{x} y^{\prime \prime}=M_{x}, \\
E I_{y} x^{\prime \prime}=M_{y},
\end{array}\right.
$$

where $x, y$ - principal axis of section;

$M_{x}, M_{y}$ - bending moments;

$I_{x}, I_{y}$ - axial inertia moments. 
Elements' twisting and associated shear stresses are not taken into account. The supports reaction calculated with this approach embodies the loads on adjacent ACTS elements.

Such systems' stress-strain state true nature differs substantially from that approach. This is due primarily to the fact that all the structural elements are thin-walled, and there arise specific force factors that are unique to the thin-wall elements; also some associated additional stresses take place, which in thin rods theory are called sectorial stresses [4].

At the same time the total stress

$$
\sigma_{z}=\frac{M_{x}}{I_{x}} y+\frac{M_{y}}{I_{y}} x+\frac{B_{\omega}}{I_{\omega}} \omega
$$

where $B_{\omega}$ - bending \& twisting bi-moment;

$I_{\omega}$ - inertia sectorial moment;

$\omega$ - sectorial area,

and the mathematical is described with a differential equations' system

$$
\left\{\begin{array}{l}
E I_{x} y^{\prime \prime}=M_{x} \\
E I_{y} x^{\prime \prime}=M_{y} \\
\theta^{\mathrm{IV}}-k^{2} \theta^{\prime \prime}=\frac{m}{E I_{\omega}},
\end{array}\right.
$$

where $k^{2}=\frac{G I_{d}}{E I_{\omega}}$;

$G I_{d}$ - twisting stiffness.

To be noted is that in most finite elements CAD it is possible to leave the model described by equations (1), passing to the model based on the equations (2) by selecting the specific finite element at $\mathrm{FE}$ approximation.

The proposed boundary-element model also uses these equations (2).

It is known [3], that the main values characterizing the N\&A BEM model are the fundamental matrix of the problem $\bar{A}_{*}$ - block-diagonal matrix, the vectors of loads $\vec{B}$ and boundary parameters $\vec{X}_{*}, \vec{Y}$. The components of these matrices were derived analytically.

The system under consideration consists of two side members and fifteen cross members, divided into 43 mono-dimensional modules (Fig. 2), so the vectors $\vec{X}_{*}, \vec{Y}, \vec{B}$ are composed of 344 elements and the orthonormal basic functions matrix $\bar{A}_{*}-$ square matrix of size $344 \times 344$.

The orthonormal basic functions matrix elements and load matrix elements are obtained for ACTS of open-profile thin-walled rods,

$$
\begin{gathered}
A_{13}=\operatorname{ch} k x-1 ; \quad A_{14}=\frac{\operatorname{sh} k x-k x}{k} ; \quad A_{23}=k \operatorname{sh} k x ; \quad A_{33}=\operatorname{ch} k x ; \quad A_{34}=\frac{\operatorname{sh} k x}{k} ; \\
B_{11}=M_{k p}\left[\frac{\operatorname{sh} k\left(x-\mathrm{a}_{1}\right)_{+}-k\left(x-\mathrm{a}_{1}\right)_{+}}{k}\right]+m\left[\frac{\operatorname{ch~} k\left(x-\mathrm{a}_{2}\right)_{+}-H\left(x-\mathrm{a}_{2}\right)}{k^{2}}-\frac{\left(x-\mathrm{a}_{2}\right)_{+}^{2}}{2}\right]- \\
-\left[\frac{\operatorname{ch} k\left(x-\mathrm{a}_{3}\right)_{+}-H\left(x-\mathrm{a}_{3}\right)}{k^{2}}-\frac{\left(x-\mathrm{a}_{3}\right)_{+}^{2}}{2}\right]+B_{\omega}\left[\operatorname{ch} k\left(x-\mathrm{a}_{4}\right)_{+}-H\left(x-\mathrm{a}_{4}\right)\right] \\
B_{21}=M_{k p}\left[\operatorname{ch~} k\left(x-\mathrm{a}_{1}\right)_{+}-H\left(x-\mathrm{a}_{1}\right)\right]+m\left[\frac{\operatorname{sh} k\left(x-\mathrm{a}_{2}\right)_{+}}{k}-\left(x-\mathrm{a}_{1}\right)_{+}\right]- \\
-\left[\frac{\operatorname{sh} k\left(x-\mathrm{a}_{3}\right)_{+}}{k}-\left(x-\mathrm{a}_{3}\right)_{+}\right]+B_{\omega} \cdot k \operatorname{sh} k\left(x-\mathrm{a}_{4}\right)_{+}
\end{gathered}
$$




$$
\begin{gathered}
B_{31}=-M_{k p} \frac{\operatorname{sh} k\left(x-\mathrm{a}_{1}\right)_{+}}{k} m\left[\frac{\operatorname{ch} k\left(x-\mathrm{a}_{2}\right)_{+}-H\left(x-\mathrm{a}_{2}\right)}{k^{2}}-\frac{\operatorname{ch} k\left(x-\mathrm{a}_{3}\right)_{+}-H\left(x-\mathrm{a}_{3}\right)}{k^{2}}\right]- \\
-B_{\omega} \cdot k \operatorname{ch} k\left(x-\mathrm{a}_{4}\right)_{+} ; \\
B_{41}=-M_{k p} \cdot \operatorname{ch} k\left(x-\mathrm{a}_{1}\right)_{+}-m \frac{\operatorname{sh} k\left(x-\mathrm{a}_{2}\right)_{+}-\operatorname{sh} k\left(x-\mathrm{a}_{3}\right)_{+}}{k}-B_{\omega} \cdot k \operatorname{sh} k\left(x-\mathrm{a}_{4}\right)_{+} .
\end{gathered}
$$

Results. The considered semi-trailer platform structure (Fig. 1) is calculated on two different models' basis: the finite elements and boundary-elements. The three identified hazardous stress points are determined during field tests at various movement modes that allowed to estimate the proposed models' effectiveness.

We investigated three points: cross wall at the junction to the spar (point 1); spar's lower shelf bearing maximum stress (point 2); spar wall in place of rear mount (point 3).

The results of calculations and experimental data for the points 2 and 3, the three modes of movement being studied, are shown in Table 1, the calculation errors are indicated in Table 2.

Table 1

Stress values obtained through two methods and experimentally

\begin{tabular}{c|c|c|c|c|c|c|c|c|c|c}
\hline \multirow{2}{*}{$\begin{array}{c}\text { № } \\
\text { point }\end{array}$} & \multirow{2}{*}{$\begin{array}{c}\text { Load } \\
\text { position }\end{array}$} & \multicolumn{8}{|c|}{ Stress, MPa } \\
\cline { 3 - 12 } & & \multicolumn{2}{|c|}{ Straight movement } & \multicolumn{3}{c}{ Turn to the right } & \multicolumn{3}{c}{ Turn to the left } \\
\cline { 3 - 12 } & operation & FEM & BEM & operation & FEM & BEM & operation & FEM & BEM \\
\hline \multirow{2}{*}{2} & initial & 20,1 & 19,20 & 19,33 & 18,0 & 17,1 & 18,74 & & & \\
\cline { 2 - 12 } & shift & 19,75 & 18,88 & 20,65 & 16,2 & 16,82 & 17,12 & 19,85 & 18,93 & 20,69 \\
\hline \multirow{2}{*}{3} & initial & 7,9 & 8,31 & 8,24 & 6,5 & 6,14 & 6,24 & & & \\
\cline { 2 - 12 } & shift & 9,2 & 8,85 & 9,75 & 5,15 & 5,0 & 5,36 & 11,4 & 10,89 & 11,87 \\
\hline
\end{tabular}

Table 2

Calculation error

\begin{tabular}{c|c|c|c|c|c|c|c}
\hline \multirow{2}{*}{$\begin{array}{c}\text { № } \\
\text { point }\end{array}$} & \multirow{2}{*}{ Load position } & \multicolumn{6}{|c}{ Error respectively to experimental data, \% } \\
\cline { 3 - 8 } & & \multicolumn{2}{|c|}{ Straight movement } & \multicolumn{2}{c}{ Turn to the right } & \multicolumn{2}{c}{ Turn to the left } \\
\cline { 3 - 8 } & & FEM & BEM & FEM & BEM & FEM & BEM \\
\hline \multirow{2}{*}{2} & initial & 4,47 & 3,83 & 5,0 & 4,11 & & \\
\cline { 2 - 8 } & shift & 4,41 & 4,56 & 3,83 & 5,68 & 4,63 & 4,23 \\
\hline \multirow{2}{*}{3} & initial & 5,19 & 4,3 & 5,54 & 4,0 & & \\
\cline { 2 - 8 } & shift & 3,8 & 5,98 & 2,91 & 4,1 & 4,47 & 4,1 \\
\hline
\end{tabular}

Conclusions. Analysis of the results obtained shows that the error between the calculation results obtained on the basis of two numerical methods and experimental data is about $4 \%$, that indicates the proposed mathematical model adequacy.

These results implementation at "VESTT ACC" LLC (Odessa) showed that the use of models based on numerical-analytical boundary element method allowed to reduce the weight of the semitrailer platform by $18 \%$, and the use of computer-aided design package developed led to an average reduction in design time of $20,4 \%$.

\section{Література}

1. Zienkiewicz, O.C. The finite element method for solid and structural mechanics / O.C. Zienkiewicz, R.L. Taylor, D.D. Fox. $-7^{\text {th }}$ Edition. - Amsterdam: Elsevier, 2014. - 624 p.

2. Eslami, M. Reza. Finite elements methods in mechanics / M. Reza Eslami. - Cham, Switzerland: Springer, 2014. - $370 \mathrm{p}$.

3. Численно-аналитический метод граничных элементов / А.Ф. Дащенко, Л.В. Коломиец, В.Ф. Оробей, Н.Г. Сурьянинов. - В 2 т. — Одесса: ВМВ, 2010. — Т. 1. — 416 с. — Т. 2. - 512 с. 
4. Туснін, О.Р. Кінцевий елемент для чисельного розрахунку конструкцій з тонкостінних стержнів відкритого профілю / О.Р. Туснін // Металеві конструкції. — 2009. — Т. 15, № 1. — С. 73 - 78.

\section{References}

1. Zienkiewicz, O.C., Taylor, R.L. and Fox, D.D. (2014). The Finite Element Method for Solid and Structural Mechanics $\left(7^{\text {th }}\right.$ Ed.). Amsterdam: Elsevier.

2. Eslami, M. Reza. (2014). Finite Elements Methods in Mechanics. Cham, Switzerland: Springer.

3. Dashchenko, A.F., Kolomiets, L.V., Orobey, V.F. and Suryaniniv, N.G. (2010). Numerical-Analytical Boundary Element Method (Vols. 1-2). Odessa: VMV.

4. Tusnin, A.R. (2009). Finite element for numeric computation of structures of thin-walled open profile bars. Metal Constructions, 15(1), 73-78. 